\title{
A rediscovery of the priesthood of believers in Ephesians 4:1-16 and its relevance for the Missio Dei and a biblical missional ecumenism
}

\begin{tabular}{|c|c|}
\hline \multicolumn{2}{|c|}{$\begin{array}{l}\text { Authors: } \\
\text { George Lotter }{ }^{1} \\
\text { Timothy van Aarde }\end{array}$} \\
\hline \multicolumn{2}{|c|}{$\begin{array}{l}\text { Affiliations: } \\
{ }^{1} \text { Faculty of Theology, } \\
\text { Potchefstroom campus, } \\
\text { North-West University, } \\
\text { South Africa }\end{array}$} \\
\hline \multicolumn{2}{|c|}{$\begin{array}{l}{ }^{2} \text { Department of Humanities, } \\
\text { Vanderbijlpark campus, } \\
\text { North-West University, } \\
\text { South Africa }\end{array}$} \\
\hline \multicolumn{2}{|c|}{$\begin{array}{l}\text { Corresponding author: } \\
\text { George Lotter, } \\
\text { george.lotter@nwu.ac.za }\end{array}$} \\
\hline \multicolumn{2}{|c|}{$\begin{array}{l}\text { Dates: } \\
\text { Received: } 08 \text { Mar. } 2017 \\
\text { Accepted: } 13 \text { June } 2017 \\
\text { Published: } 31 \text { Aug. } 2017\end{array}$} \\
\hline \multicolumn{2}{|c|}{$\begin{array}{l}\text { How to cite this article: } \\
\text { Lotter, G. \& van Aarde, T., } \\
2017 \text {, 'A rediscovery of the } \\
\text { priesthood of believers in } \\
\text { Ephesians } 4: 1-16 \text { and its } \\
\text { relevance for the Missio Dei } \\
\text { and a biblical missional } \\
\text { ecumenism', In die Skriflig } \\
51(2) \text {, a2251. https://doi. } \\
\text { org/10.4102/ids.v51i2.2251 }\end{array}$} \\
\hline \multicolumn{2}{|c|}{$\begin{array}{l}\text { Copyright: } \\
\text { (C) 2017. The Authors. } \\
\text { Licensee: AOSIS. This } \\
\text { is licensed under the } \\
\text { Creative Commons } \\
\text { Attribution License. }\end{array}$} \\
\hline \multicolumn{2}{|l|}{ Read online: } \\
\hline 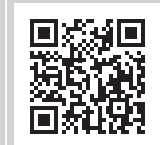 & $\begin{array}{l}\text { Scan this QR } \\
\text { code with your } \\
\text { smart phone or } \\
\text { mobile device } \\
\text { to read online. }\end{array}$ \\
\hline
\end{tabular}

This article is dedicated to Professor Sarel van der Merwe as missiologist and what he had done for the cause of the missio Dei in South Africa. The role of the laity in the missio Dei was one of the most significant developments followed by most church denominations. The priesthood of believers was the reformational perspective rediscovered by Martin Luther. The reformed tradition rediscovered the role of the laity in missions, which the Baptist church tradition has now developed most extensively in terms of missions. The Catholic Church has recognised the apostolicity of the laity in a decree called 'Apostolicam Actuositatem' at the Second Vatican Council in response to the crises of the church. The charismatics gave recognition to the role of the laity through the spiritual gifts of each believer. The role of the laity and of the priesthood of believers has its biblical precedent and foundation in 1 Peter 2:5, 9 and Ephesians 4:1-16. The contribution of Ephesians is that it provides the church with a missional mandate for the ordinary believer to participate in the missio Dei -, a mandate that has to be rediscovered in every age. The priesthood of believers provides an orientation for a biblical missional ecumenism.

\section{Introduction}

This article is dedicated to Sarel van der Merwe as a missiologist par excellence. Not only was he a missionary in the true sense of the word by being 'out in the field'; he also took it a step further by starting to train missionaries, evangelists and ministers to proclaim the gospel on other levels.

It started as a mission project in Mareetsane, developed into the College ya Mojadi and eventually the Department of Theology on the Mafikeng Campus of North-West University and Sarel van der Merwe was instrumental in having all these things happen (Brunsdon \& Van der Merwe 2013:295). Even while involved in administration and management, he never lost his 'missionary heart' which was always the driving force in Van der Merwe's life. We therefore commend him for

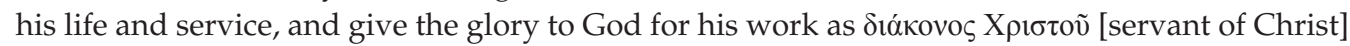
and as one who devoted his whole life to the missio Dei.

The priesthood of believers is a practical, lived-out doctrine that facilitates better and deeper church and inter-denominational relationships. It is vital to the fostering of a biblical missional ecumenism. In the era of post-Christendom, all churches and denominations in the West are facing the same challenge of the marginalisation of Christianity to the fringes of society.

One of the central questions of the participation of ordinary believers in missions is the following: 'What is the role of the laity in mission, and how can the clergy enhance and promote lay missional movement?' (Sunquist 2013:308). Mission in the West has traditionally been identified as the task of the clergy or missions experts. A movement of the rediscovery of the priesthood of believers through the focus of the missio Dei is critical in an age of post-Christendom in the West, because the special giftedness of the laity exists in a variety of ways for carrying out the mission of God. The task of the clergy in preparing the laity is that of the priestly role of equipping and empowering them to be sent out into their neighbourhoods. 'It is imperative that each local church find ways of releasing and empowering the laity to do the work of the mission of God' (Sunquist 2013:309). One of the reasons for the phenomenal growth of the church in the global south, Africa, Asia and South America is that the laity participates in the missio Dei. David Bosch anchored the participation of the laity in the missio Dei in the Word of God and the sacraments, but this view still excludes the laity's full participation in the missio Dei, because these are administered by the ordained ministry. The Reformation was a movement of the rediscovery of the ministry and mission of the believer and that: 
mission does not proceed from the pope, nor from a missionary order, society, or synod, but from a community gathered around the word and the sacraments and sent into the world. (Bosch 2016:472)

'The Reformation treasured the priesthood of believers, but it was the revivals and the missionary movement of the nineteenth century in which the priesthood of all believers really took on flesh' (Sunquist 2013:118). The involvement of the believer in the missio Dei necessitates a recovery of the priesthood of believers as the emphatic practice of the Reformation. The missio Dei is central to the missionary movement that will restore the priesthood of the believer to its central place in the church. It will require a reconsideration of the following: the tradition of the separation of the clergy and the laity in the Catholic tradition, the one category of pastor-missionary in the Lutheran tradition, the distinction between the special gifts and administration and leadership gifts in the Pentecostal and charismatic tradition, and the relation of the offices and the laity in the reformed tradition.

\section{The need for a new focus on the priesthood of believers}

The Protestant Reformation gave a central focus and relevance to the submerged doctrine of the priesthood of believers (cf. Coleman 2011:216). The accent in the Reformation, however, has been placed on the access to God (Eph 2:18), so that 'the eternal purpose, which God carried out in Jesus Christ' (v. 11), is understood primarily as access to God, 'in whom [Christ] we have boldness and confident access through faith in Him' (v. 12). The result is that there is a disconnection in thought between access to God and the task of the church (Eph 3:8-10), the individual calling (v. 1-3) and task of all believers (v. 7-16). For every believer it is particularly the vertical aspect of access to God and the immediacy of Christ that became the central conception of the priesthood of believers in the 19th century. In most churches the horizontal dimension of 'outreach to our fellow men' is a ministry 'still largely consigned to duly ordained clergyman or especially favored local leaders' (Coleman 2011:216). The priesthood of believers is a fellowship with Christ in which members of his body are also members of one another. A recovery of the complete and comprehensive understanding of the priesthood of believers has to be in terms of the vertical spirituality of the mystical communion of every believer with Christ as well as the horizontal ministry of all believers (Eph 2:18; 3:12; 4:12). Instead of the priesthood of the believers being a unifying doctrine it has become enamoured with our own ecclesiastical distinctiveness to the extent that other members of the universal church are disowned. In terms of its proper function it has the inherent potentiality to be a community-building concept of the church's ministry - a concept by means of which ministry is lifted 'into the daily life of mothers, factory workers, clerks, farmers, students - [in which] every Christ-honouring vocation becomes of service and every location a place of witness' (Coleman 2011:217). The confession that 'there is one Body and one Spirit ... one Lord, one faith, one baptism, one
God and Father of all' (Eph 4:4-6) and its relation to the function of the gifts in the church (v. 7-16), is to be read in terms of a plurality of ecclesiastical distinctive groups who, in their distinctive understanding and functioning, contribute to a holistic understanding of the priesthood of the believers. Each ecclesiastical distinctive church group can make a unique contribution to a comprehensive understanding of the priesthood of believers. 'It is imperative that each local church find ways of releasing and empowering the laity to do the work of the mission of God' (Sunquist 2013:309).

In this article the understanding of 'the priesthood of believers' and its praxis in the mainline Christian denominations and the Pentecostal-charismatic movement, as one of the largest recent church growth movements, will be explored. The various denominational understandings will be related to a biblical exposition of the priesthood of believers in light of Ephesians, specifically Ephesians 4:1-16.

\section{The missional vocation of nurturing}

The missional calling and vocation of the believer is to create a nurturing missional culture in the church. The calling of every believer is to the vocation of nurturing - to both those who are part of the body of Christ and those on the outside. There is no single definitive way to categorise participation of laypersons in lay ministry and missions. The priesthood of believers has the objective of one laity and clergy working together harmoniously for the well-being of the body of Christ, which is the function of the confession of Ephesians 4:4-6. The participation of the laity may take the form of inclusion in the liturgy, which may entail a deeper experience of the liturgy, pastoral visitation, laypersons assisting the clergy at the local homeless shelter, visiting the sick or imprisoned, and discipleship programs and missions. It is the critical challenge of the missional church movement to nurture a missional vocation and calling among all believers so that, through the priesthood of believers, the laity may be involved in mission and, more than this, that they become 'the initiators of mission' (Sunquist 2013:309). The primary function of church leadership is to equip the believers for $\delta 1 \alpha \kappa o v i ́ \alpha$ [service] and oikovouía [mission]. It is in Ephesians 4:1-16 that the corporate community is presented as 'the priesthood of believers' to be equipped to serve and fulfil its missional vocation and calling. ${ }^{1}$

\section{The missional view of the 'gifts of grace'}

'The universal priesthood of all believers should be reflected not only in the exercise of authority, but also in the exercise of the different gifts of the Holy Spirit' (Roldán 2004:161). It is the gifts of the Spirit that makes the life and mission of the church possible (cf. Roldán 2004:162). John Driver (1976) writes:

The church will be truly the body of Christ to the extent that all the gifts of the Spirit are recognized and exercised in the community. The plurality (whereby more than one person can

1.The language used envisages God's people collectively ('we all' Eph $4: 13$, 'we' v. 14-15), but in terms of functionality each individual member is to function properly for the body to be build up and out (v. 16). 
exercise a single gift), and the universality (whereby every member has a gift or gifts to use) are part of the very essence of the church. (p. 30)

The grounds for the giving of the gifts is indicated in Ephesians 4:8 as the 'captivity of captivity', which means that a new covenant dispensation has been inaugurated in which the ascended Christ has given and continues to give gifts to people. The pre-requisite for the receiving of these gifts of grace is salvation. In the charismatic tradition spiritual gifts are gifts received upon the baptism of the Spirit. In Ephesians 4:8-12 the operation of the gifts of grace is indicated as a consequential development of salvation of the believer in Ephesians 2:1-10 that is worked out in terms of its function in the body of Christ. 'The gifts present in the body are joined together so that the work of each part contributes to the strengthening of the whole' (Van Rheenan \& Parker 2014:332). The body is nurtured as each member of the church uses the gifts of grace he or she has received. The intention of the gifts is the nurturing of the body of Christ and through the priesthood of believers in the society. 'All God's people are called and gifted for ministry. This is what is meant by the Protestant teaching about the priesthood of all believers' (Jørgensen 2012:26). According to Balia and Kim (2010), the priesthood of believers is essential to the church structure:

We still need priests and pastors, as we need other leadership functions (teacher, evangelist, apostle, prophet - Eph 4:11), but the basic structure for the local church and for mission is the priesthood of all believers. (p. 120)

\section{The missional equipping with the 'gifts'}

The church structure in Ephesians is presented as a missional church structure and in the missional church model the saints are to be equipped by the gifted ones for the work of the ministry (Eph 4:12). The gifted ones (Eph 4:11) possess the missional functions of apostle, priest, evangelist, pastor and teacher. It is not the offices in the church that are in view. ${ }^{2}$ The gifted ones are people who function in these gifts given to the church to equip the believers to function missionally. Hastings (2012) comments as follows:

Whereas the teaching of the pastor-teaching is dominant in many evangelical churches, room will be made in missional churches for the other three strategic leadership gifts of apostle, prophet and evangelist (Eph 4:11), as was evident in Acts. (p. 297)

The leadership envisaged is servant leadership which

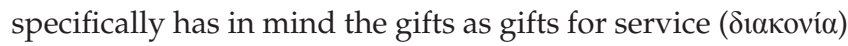
and mission (oikovouía), apostleship (mission), casting and direction, prophecy (mission), evangelism (service) and preaching (service), and that of pastor-teacher (service). The distinction between the first group (mission, apostleship, casting and direction, prophecy) and the second group (evangelism, preaching and pastor-teacher) is that the first group is directed towards helping the church fulfil its missional calling in society and outside the community, while the second group is directed inwards to help the church fulfil 2.The alternative is a continuation of the offices of prophet and evangelist in the church. its calling to the community, that is, the church. A distinction between function and office implies the functions reserved for those set apart for ordained office in contrast to the functions that ordinary believers can perform: this is a necessary pre-requisite for the effective functioning of the body of Christ. 'The primary task of the servant leader is to equip others for service. This is the core of Ephesians 4:11-16 where Paul describes the service/diakonia of all God's people' (Jørgensen 2012:25). The parameters of lay ministry in juxtaposition to the ordained office have to be clarified.

\section{The Lutheran view of the 'gifts'}

The term gifts as used in Ephesians indicates that from the perspective of the author there was neither spiritual distinction nor office in view in the use of this term. Luther's view was that the process of ordination did not constitute the clergy as a distinct 'spiritual' (viz. clerical) class, or Christians ontologically distinct from and superior to the 'temporal' (viz. lay) order; instead, he insisted that 'all Christians are of the spiritual estate [Stand], and there is no difference between them except that of office' (cf. Wengert 2011:408-409).

In the Lutheran view apostle, prophet, shepherd and teacher are 'gifts' of those who hold offices (Eph 4:11). The 'gifts' of apostle and evangelist are used for ecclesiastical backing of the missionary office. The missionary office is a rite vacates and it is in this respect not different from that of the pastor (cf. Schultz 2009:273). In the Lutheran tradition there is no distinction made between the office of missionary and those of pastor. The apostolic office is continued through the office of preaching (2 Cor 5:19-20; Rom 10:9-10) that involves two aspects, namely outreach and in-reach: a missionary and pastor's office are two aspects of the one apostolic office. The mandate given to the church is a single preaching mandate that is differentiated into two offices: pastor and missionary. The missionary office is, however, not integrated into the leadership of the local church: in the local church context the pastor fulfils both functions and on the mission field the missionary fulfils both functions. According to Holsten (1939):

The missionary must be rite vocatus; an individual's call experience does not warrant sufficient legitimization. Essentially, the right to serve as a 'free' standing missionary is rejected and the status of a society's missionary is only legitimate in so far as his calling or commission is not extended from a society that stands in deliberate isolation from the church, which (the church) has no other signs (not) to show forth than the right proclamation of the Gospel and administration of the Sacraments. (p. 14)

Luther transformed the use of the words calling and vocation by assigning it to all Christians. In Ephesians 4:1 each and every believer is to live 'in a manner worthy of the calling with which you have been called'.

\section{The priesthood of believers in Lutheranism}

It is Martin Luther who affirmed that all Christians have a calling. Luther (in both The Babylonian captivity of the church 
and Letter to the Christian nobility [An den christlichen Adel deutscher Nation - 1520]) affirmed the priesthood of all believers and denied that a special priesthood belonged to any class in the church (cf. Baldovin 2011:408-409). ${ }^{3}$ Luther bases his theology of all believers' equality on the basis of the theology of Baptism and draws on the language of 1 Peter 2:9 in which the whole church is described as a 'royal priesthood' (cf. Wengert 2011:408-409). The Lutheran approach to the priesthood of believers was 'to restore the common Christians access to God' (Rogers 2010:121). The priesthood of believers is understood as having the task of the laity, namely to permeate the world through service and testimony. The task of the laity is the service of love towards one another for the unity of the body of Christ and service to society. Schultz (2009:238) argues that 'such a work of service would also include the task of sharing the Gospel with non-Christians', but this is not the general understanding of the task of the laity. The task is often confined to the 'calling' or 'vocation' to 'live a life worthy of the calling you have received' (1 Cor 7:20 - New International Version). The King James Version (KJV) is followed in the translation of Ephesians 4:11-12 in which a comma is placed after 'saints' and before the prepositional phrase 'for the work of the ministry'. It means that through the insertion of the comma, (not found in the Greek text), the Lutheran Church has adopted in its confessional documents that the work of the ministry is done by the ordained clergy and that it is the exclusive task of the ordained clergy to build up the body of Christ. It is the task of the ordained clergy to perfect both the inward and outward lives of the believers. The priesthood of the believers is limited to the immediacy of access to God (cf. Rogers 2010:121). ${ }^{4}$ The task of the laity is thus the obligation to pass witness in his personal sphere of life and sacrifice in service to the neighbour without the verbal preaching of the gospel (cf. Schultz 2009:242). Luther made a distinction between the public and private ministry of God's Word (cf. Rogers 2010:124). More has to be done to recognise the equality of these forms of preaching. 'The emphasis in Luther's doctrine of the priesthood of believers is on Christ's priestly work' (Rogers 2010:122), and the private priestly work of the believer. The priesthood of believers in Luther's understanding is community-centred with each believer serving as priest to other believers (cf. Rogers 2010:123) - but not world-centred. As a result, the public and private spheres are separated in the Lutheran view - 'a Christian has to live according to two contradicting sets of norms' (Van der Walt 2011:11) - with the result that the priesthood of the believers is practised only in the private sphere. To transform society, it is necessary for Lutherans to integrate the public and private spheres and norms in the exercise of the priesthood of believers. ${ }^{5}$ The laity needs to be involved in the performing of functions that have generally been considered to be exclusively priestly functions. The reason that a distinction continues to exist between laity and the clergy is that, although the laity are included in ministry,

3.Luther himself never used the phrase priesthood of all believers. He affirmed that Christians 'are all consecrated priests' (cf. Wengert 2011:408-409).

4.'Luther sought to restore the common Christian's access to God' (Rogers 2010:121).

5 .In Lutheranism the church and culture are in paradox. mission is still conceived of as the task of the ordained ministry. This is a focus the priesthood of believers in Ephesians can address in that the sharing of the gospel by ordinary believers is inseparably connected to 'access to God' - the basis of the priestly role of the believer in the priesthood of the believer.

\section{The Baptist view of the priesthood of believers}

The priesthood of believers for Baptists is intensely personal but never individualistic (cf. Young 1993:143). It is virtually inseparable from Baptist doctrine (cf. Young 1993:132). ${ }^{6}$ 'Until very recently virtually every Baptist would have argued that there is no more basic belief to Baptists than the idea of the priesthood of the believers' (Young 1993:132). Cyril Eastwood's conclusion is that 'the doctrine of the priesthood of the believers is not incidental but central in Baptist theology' (cf. Young 1993:132). ${ }^{7}$ The Baptist concept of the priesthood of believers is the 'soul competency, meaning that all persons are capable of approaching God directly, without interference or the assistance of an intermediary' [author's emphasis] (Young 1993:131). Soul competency has not been understood from a political perspective but from a sociological perspective as 'religious liberty', meaning the full freedom to worship 'according to their own interests and needs, with no coercion from the state, the church, or individuals' (Young 1993:131), but this is not synonymous with soul competency. Young (1993) also added that:

Mullins ${ }^{8}$ saw soul competency, which he also called priesthood of the believer and religious liberty, to be an axiom, a truth so basic as to need no proof, so obvious that any intelligent person will agree to it after reasonable consideration. (p. 134)

This, however, was a confusion of various concepts. In the Baptist view, the concept of the priesthood of believers is informed by the biblical tradition of an exposition of Exodus 19:5-6. However, in Ephesians 3:11-12, 1 Timothy 2:5 and Revelations 1:4-6, the focus is on the soul competency of the believer (cf. Young 1993:132) which is founded on the believer's relationship with Christ. Mullins equates the priesthood of believers with competency of the soul in which the relationship with Christ is superior to all other relationships. 'Religious liberty' means that 'the Christian should be against any political involvement, because Christian life as such is dirty and evil and a contradiction to the Christian life' (Van der Walt 2011:28). The Baptist concept of religious liberty is framed by a worldview of grace opposes nature that results in practices in which 'the real Christian' is to be against the world, retreating into his alternative church consisting of really holy or separated people (cf. Van der Walt 2011:10). The conceptualisation of soul competency belongs to the private sphere and has the meaning of spiritual access

6.There are 17 points where the priesthood of believers relates to basic Baptist doctrine (cf. Young 1993:132)

7.'The priesthood of all believers', and 'The royal priesthood of the faithful'.

8.'E.Y. Mullins may be the single most important theologian in Southern Baptist history. He was president of Southern Baptist Theological Seminary (1899-1928). history. He was president of Southern Baptist Theological Seminary (1899-1928).
He also served as president of the Southern Baptist Convention (1921-24) and of the Baptist World Alliance (1928)' (Young 1993:133). 
of the believer to God and the immediacy of Christ. 'Religious liberty, for Mullins, is the inevitable counterpart of soul competency' (Young 1993:134). Young identifies 'religious liberty' with the priesthood of believers, which is a confounding of two distinct concepts, with the freedom of religion which belongs to the public sphere, and with soul competency which belongs to the private sphere. ${ }^{9}$ The worldview of grace opposes nature is the consequence of the equating of religious freedom and soul competency. Religious freedom, in Mullins' view, was based on the believer's access to God. The confusion of these two distinct spheres results in a radical discontinuity between Christianity and culture. The result is an isolation of Christianity from its surrounding culture (cf. Van der Walt 2011:61). 'Consequently, it cannot really challenge its cultural environment' (Van der Walt 2011:61). A distinction has to be maintained between 'religious liberty' and the freedom of conscience to worship (which is the basis of democratic congregational authority) and soul competency, which is the basis of the believer's relation to God and the priesthood of the believer, the ministry of the believers. Mullins associated soul competency with the Western ideal of individualism. ${ }^{10}$ ' $\mathrm{He}$ did not talk about the responsibility of each Christian to serve as a priest for his neighbour' (Rogers 2010:131). In Luther's view the believer was a priest to the body - the church - and he did not extend the responsibility to be a priest to society. Mullins' view can be typified as 'the right to private judgement' (Rogers 2010:131) or freedom of conscience. It should not be confused with 'religious liberty', which has to do with the relationship of church and state, and the withdrawal from politics and society. It is only in recognising the distinctiveness of these concepts that Baptists are able to engage injustices in society, which is the social aspect of the priesthood of believers. ${ }^{11}$ The priesthood of believers flows out of soul competency, but it is not identical with it. The Baptist approach to missions is individualistic and a mission's emphasis, based on a biblical emphasis on community, is badly needed (cf. Goheen 2014:313). For this reason, missions in the Baptist tradition are to be grounded in more than only soul competency; rather it should not be an almost exclusive focus on the restoration of healthy relationships without considering political, social, cultural and economic dimensions of the gospel.

\section{The Catholic view of the priesthood of all believers}

In an important development in Roman Catholic theology, Pope Paul VI issued the decree Apostolicam Actuositatem [Apostate of the Laity], which outlined the important role the laity play in the mission of the church. In the Apostolicam Actuositatem, promulgates on 18 November 1965, Pope Paul VI issued a holy decree on the vocation of the laity and apostate in which he cites Ephesians (Second Vatican Council 1965):

\footnotetext{
9.Mullins takes 'the priesthood of the believer' to be a synonym for soul competencythe access of the believer to God.

10.'Mullins believed the Baptist principle of soul competency was consistent with the Western ideal of individualism' (Rogers 2011:131).

11.The Baptist position is church against culture.
}

For the Christian vocation by its very nature is also a vocation to the apostolate. No part of the structure of a living body is merely passive but has a share in the functions as well as life of the body: so, too, in the body of Christ, which is the Church, 'the whole body ... in keeping with the proper activity of each part, derives its increase from its own internal development' (Eph. 4:16). (p. 37).

Recent decades have seen this theology of mission reinforced, not only in the Catholic Church, but also in global Christianity:

In the Church there is a diversity of ministry but a oneness of mission. Christ conferred on the Apostles and their successors the duty of teaching, sanctifying, and ruling in His name and power. But the laity likewise share in the priestly, prophetic, and royal office of Christ and therefore have their own share in the mission of the whole people of God in the Church and in the world. (Sunquist 2013:308)

In 1987 a Catholic synod was held in which the role of the pastors was to foster the Holy Spirit's activity in the laity:

The New Code of Cannon Law reflects Vatican II's theology of the laity. It says, in can. 275,2 , that 'clerics are to acknowledge and promote that mission which lay persons experience in their own way in the church and the world. (Rivers 2005:178)

Pope John Paul II pointed out that the task of the ministerial priesthood is essentially to support and encourage the priesthood of the laity (cf. Rivers 2005:173). The parishioner has a calling to engage in lay ministry and discipleship as a means to actively live out their baptismal call in their daily lives (cf. Rivers 2005:174). Baptism in Catholic life and faith has the meaning of the spiritual significance of calling every person to share in the evangelising activities of the parish. 'Through baptism, all the members have gifts to share' (Rivers 2005:179). In the Catholic recovery of the priesthood of the believers through the Second Vatican Council, a richer and deeper meaning to baptism has been advocated that was closer to that of Lutheranism. The vital role of the laity in all aspects of the local parish has been fostered and lay professionals and volunteers have been drawn into service based upon 'the giftedness of baptism' and 'the very partnership of salvation' (Rivers 2005:179). The Catholic view of the separation of clergy and laity is based on the view that grace perfects nature (cf. Van der Walt 2011:25-26). ${ }^{12}$ 'To be an ordinary member of the church (a layman) is good, but to belong to the clerical order is better' (Van der Walt 2011:10). The practical application of a transformed practice of the priesthood of believers, if not accompanied by a reformation of the worldview of grace perfects nature, does not result in a reform of the Catholic Church worldview from inside, that is, it remains external or extrinsic and unable to change it internally:

It is, however, not in a position to really change or transform nature, because nature has a legitimate place of its own and grace has been separated from it beforehand. (Van der Walt 2011:9)

The traditional Catholic worldview was based on a dualism between everything that is ecclesiastical, elevated and superior 12.Thomas Aquinas (1225-1274) asserted that grace completes or perfects nature (cf. Van der Walt 2001:9). 
to everything in the lower realm of 'ordinary' life (cf. Van der Walt 2001:10), but it was necessary to change this view radically. In the past 'to be an ordinary member of the church (a layman) is good, but to belong to the clerical order is better!' (Van der Walt 2011:10), but with the introduction of 'evangelisation' of John Paul II, the superior-inferior, relationship between priest and layman is in the process of transformation. The priesthood of believers is to be understood as having the task that every Catholic should break down the walls of separation between clergy and laity for the priesthood of believers to transform society. ${ }^{13}$ Contemporary Roman Catholic mission theology revolves around a number of themes: trinitarian missions, proclamation, liberation, dialogue, inculturation, holistic mission and mission to the modern culture that has been centred in the missio Dei, that mission originates with God with Ad Gentes and the roots of the missionary nature of the church in the mission of the triune God (cf. Goheen 2014:172). The Roman Catholic grounds for the missio Dei, however, are rooted in the tradition of the church and the mission of the triune God as being expressed through the tradition of the church rather than the centrality of the Word of God in the mission of the triune God. In Evangelii Nuntiandi, evangelisation finds its source in the call to the church to continue the mission of Jesus in making known the reign of Christ (cf. Goheen 2014:172). The mission of Jesus and the reign of Christ, however, are identified with liberation in the Roman Catholic tradition. 'The good news proclaims a salvation that is a liberation from everything that oppresses humankind, but above all from sin and Satan so that humankind can know God' (Goheen 2014:173). A dualism, however, exists in Roman Catholic missions between liberation from political, social, cultural and economic dimensions, and spiritual liberation - soul competency in the Baptist view that the priesthood of believers has the potential to address.

\section{The turn to 'new evangelisation'}

The Second Vatican Council brought tremendous changes in the role and functions of parishes in the Catholic life. The explosion of lay ministry in the Catholic Church unleashed the evangelising potential of the parish. It 'has changed the shape of the parish ad intra and ad extra' (Rivers 2005:180). The involvement in the parish life was nominal and the influence on society minimal. Today, Catholics choose to be involved in their parishes for spiritual reasons (cf. Rivers 2005:163). The number of priests was in short supply at a time when the Catholic Church was facing a crisis that necessitated (the institution of) the Second Vatican Council. 'Philip Murion and David De Lambo report that in 1999 almost 29, 146 laypeople were involved full - or part time in formal pastoral roles- an increase of 36\% from 1992' (Rivers 2005:174). The job description of the local parish priest 'is all but unrecognizable, compared to what it was in past years' (Rivers 2005:163). The influence of the Second Vatican has been astronomical in terms of missions - 'mission does not proceed primarily from the pope, nor from a missionary order, society, or synod, but from a community gathered around the Word of God and the sacraments and sent into the world' (Bosch 2016:483). In the greater inclusion of the laity it has been limited to church life and liturgical participation. The missional church model in the Catholic Church in which one and all understand themselves as uniquely gifted and called by God to their neighbourhood with the message of the gospel has been limited to everyone serving the neighbourhood. ${ }^{14}$ Evangeli gaudium is the apostolic exhortation on evangelism issued by Pope Francis on 24 November 2014 on evangelism. "This effort of "new evangelism" is addressed primarily to lukewarm Christians or secular societies that were once Christian' (Woods 2016:65). 'Redemptoris missio makes it very clear that the new evangelization does not replace the more traditional missionary and evangelizing activities of the church' (Woods 2016:66). The new evangelisation is directed ad intra to the former members or former Christians; mission ad gentes or mission to the peoples has been directed ad extra. 'The new evangelism is issued as a call to conversion and the revitalization of Christian life' (Woods 2016:66). The pope's call for the new evangelisation is not a call to proclaim the gospel to the unsaved, but, according to Goheen (2014):

a call to re-evangelize the vast majority of Catholics who no longer practice their faith because they are domesticated by the culture, and the phenomenon of globalization and consumerism as a global culture that impacts the whole world in terms of growing poverty and ecological damage. (p. 175)

It is the call to a rich critique of modern Western culture and especially secularisation, pluralism, individualism, globalisation and consumerism than a spiritual renewal and inner transformation, which the priesthood of believers can facilitate.

\section{The Pentecostal-charismatic view of the 'gifts'}

It is the charismatic tradition that has developed the equipping of the believers in terms of the Holy Spirit and the giving of spiritual gifts. It was the fourfold or fivefold ministry of Ephesians 4:11 that became a distinguishing characteristic of the charismatic renewal. It was a broadening of leadership to include the laity in which believers were exhorted to find their place of service and ministry in the body of Christ. The spiritual gifts are seen as the ascension gifts of Christ given to the church after his ascension to heaven. These then are special gifts of a spiritual nature and evidence of the baptism in the Spirit. 'Only after He had ascended to heaven did He become the One who would baptize with the Spirit' (Virgo 2011:30). The baptism in the Spirit is a prerequisite for the giving of the spiritual gifts. 'The gifting by the Holy Spirit meant that the division between the clergy and lay persons became less pronounced' (Plüss 2010:259). Wonsuk Ma (2007) explains the paradigm shift that of the Pentecostal movement:

The 'outpouring' of the Holy Spirit in the early twentieth century brought several powerful paradigm shifts. First, their self-

14.The Catholic Church was the first to advocate the missional understanding of the church: the church does not have a mission; it is missionary by its very nature as 'it draws its origins from the mission of the Son and the mission of the Holy Spirit, in accordance with the plan of God the Father' (Ad gentes 2). 
understanding changed drastically: from marginalized too conspicuously 'called' to 'God's ministry'. Second, it was also seen as a strong eschatological sign for the immediate return of the Lord, and this brought an urgency to their divine call to minister. Third, this 'apostolic' movement had a strong restorational expectation in the early church. Having inherited the holiness, spiritual traditions, and supernatural interventions of God, such as healings and miracles, were regularly expected. (p. 29)

The gifts of grace in the Pentecostal or charismatic tradition consisted primarily of the restoration of the apostolic and prophetic office. It is based on the view that grace perfects nature - the spiritual perfects the natural through baptism in the Holy Spirit. "The coming of the Holy Spirit (or "baptism in the Spirit" as they call it) is for empowerment, and empowerment is for witnessing' (Ma 2007:30) and so the priesthood of believers functions very effectively in this tradition. The apostle and prophetic office in Newfrontiers has a specific function: to mobilise the church for the fulfilment of the mission's mandate:

We could become more need-centered instead of apostolic and prophetic, thereby missing God's intention and forgetting the bigger picture, (like) building churches that gradually become foreign to the atmosphere of the New Testament. (Virgo 2011:98)

The text of Ephesians 2:20 is read as a foundation laid by the first apostles and prophets. The continuation of apostles and prophets is claimed on the grounds of the reading of 'the mystery' in Ephesians 3:5 as a revelation made by present day apostles and prophets not made known in previous generations (cf. Virgo 2011:114) 'the mystery' indicating a new dispensation. The categories of apostle, prophet, evangelist and pastor-teacher are interpreted as current church offices in the Pentecostal and charismatic tradition. Newfrontiers is unique in its contextualisation of these categories as gifts of the Spirit and not as church offices. It is seen as missional functions and essential to their missional church structure. 'The prophet brings direction and exhortation' (Virgo 2011:118) in the missional expansion of the church. The prophetic ministry directs the church into God's ultimate purpose and spiritual renewal (cf. Virgo 2011:119-120). The spiritual is superior to the natural, and grace stands alongside nature. The prophet does not simply preach a message of prosperity, but in continuation of the Old Testament office 'the prophet's voice needs to come like an axe to the root of our problem. He forces us to ask uncomfortable questions that lead to uncomfortable answers' (Virgo 2011:119, 120). Apostles in the Newfrontiers churches lead and guide the church to mission in the local context and impart a vision to the church for the nations. ${ }^{15}$ Roxburg (1996) speaks of the leader as an apostle in the sense that he is:

the visionary and the one who turns vision to reality and everyday life by painting the vision before our eyes and making it more attractive than the old world. (p. 70)

\section{Jørgensen (2012) says that}

The function of the apostle is needed also today - the church is still sent to the world to make disciples. The function therefore calls for people who guard the truth and make the church mobile - people who go out ahead and cross the borders of the world. (p. 39)
The priesthood of believers in this tradition mediated through singing and worship that has the potential to bring divided humanity (including the church) together (cf. Ma 2007:33). It is a priesthood in which the 'colour' lines are 'washed in the blood' and there is racial harmony (cf. Ma 2007:32). The Pentecostal tradition of the priesthood of believers, which focuses on the experience of the believer, can be strengthened through an understanding of guidance and direction for life decisions from above, as it is not only based on supernatural spiritual encounters viewed as superior to the natural guidance from below - the

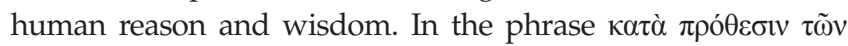

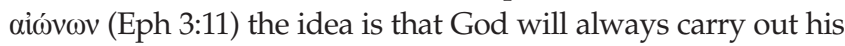

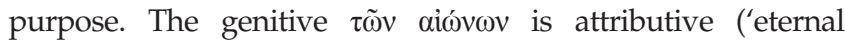
purpose'). The traditional Pentecostal-charismatic approach interprets Ephesians 4:1-16 in terms of a distinction between offices, apostle, prophet and pastor (Eph 4:11) and function the role of the believers in exercising their gifts (Eph 4:12).

\section{The Pentecostal-charismatic view of the priesthood of all believers}

Moltmann writes that, "The charismatic community is a unity in diversity and a diversity in unity. Each one as the Lord calls them, each one as the Lord endows them' (cf. Padilla 2004:172). The charismatic church structure is neither hierarchical nor bureaucratic, but has a networking nature. The charismatic church structure is a fluid structure in which there is freedom for the Holy Spirit to lead and guide the church into missions and missional expression. All the gifts in Ephesians 4:11 are needed for the believers to reach maturity and for the believers 'to be equipped for works of service' (Virgo 2011:147). The priesthood of believers is guided by the vision that every believer has a particular gift and contribution to make to the life of the church (cf. Virgo 2011:147). The role of the present day prophet and apostle is to encourage the believers to function according to the gifts of the Holy Spirit. In the Pentecostal tradition 'ministry' is liberated 'from the elite clergy to the hands of every believer' (Ma 2007:30). In the Pentecostal tradition the emphasis is placed on the prophetic function. It is the reason that Wonsuk Ma (2007) writes:

In the academic realm, a new expression has been suggested 'the prophethood of all believers,' such a possibility becoming an attractive move from the traditional notion of 'the priesthood of believers'. (p. 30) ${ }^{16}$

Pentecostal-charismatics are to unify the natural and spiritual realms in one realm for the priesthood of believers to transform society. ${ }^{17}$

\section{The biblical grounds of the priesthood of the believer in Ephesians}

A relationship exists between Ephesians 2:11-22 and 4:1-16 in which there is a link in terms of language -the building

16.Roger Stronstad (1999) argues for the term prophethood for the Pentecostal involvement of all believers in ministry has been appropriated.

17.The Pentecostal-charismatic position can be typified as Church culture above culture. 
metaphor, unity, the foundational role of apostle and prophets, which in Ephesians 4:11 is extended to include evangelists, teachers and pastors. It is used differently so that Ephesians 4:1-16 sheds light on Ephesians 2:11-22 and vice versa. The relationship between these thought units has been overlooked, because the relation has not been explored in terms of the development of the themes of Ephesians 2:11-22 in 4:1-16 and the missional intent and dimension of the letter. ${ }^{18}$ The missional dimension of the metaphor of a building in Ephesians 2:19-22 is used to visibly express the unity of Jew and Gentile, ${ }^{19}$ which in its relation to Ephesians 3:8-10 in which the missional intent of the church is expressed and both these aspects are united in Ephesians 4:1-16. ${ }^{20}$ It is practically to be a dynamic church structure, of a unified inward and outward structure, of the one building process as expounded in Ephesians 2 and 4. The believer's access to God and a restored relationship with his or her neighbour are a natural consequence or result of God's eternal plan for the church to have freedom to speak the gospel (Eph 3:11-12). It is practically worked out in terms of God's eternal plan for the church indirectly 'to make known the manifold wisdom of God to the rulers and the authorities in the heavenly realms through the church' (Eph 3:10) as part of God's 'eternal purpose' (Eph 3:11). The focus is not the relationship of believers to one another and to God in Ephesians 3:12, but on the relationship of believers to the world and to Jesus Christ. ${ }^{21}$ The manifold or richly abundant wisdom of God is displayed by what the church collectively does by missions and its self-understanding as being missional rather than by its mere existence that has, for the most part, been the interpretation of Ephesians - specifically Ephesians 3:10. The object in Ephesians 3:11, $\pi \rho$ ó $\theta \varepsilon \sigma v$, to which is attributed the qualification of 'eternal' means that God's plan or purpose will always be carried out. This is a basic premise of missions. The traditional interpretation of Ephesians 3:12 is that the believers have access to God as the gift of forgiveness of sins that is apprehended through faith. In this interpretation, access to God is through the justification of the believer. If this interpretation is followed, the relationship between Ephesians 2:18 and $3: 12$ is that peace is the evidence or result of the righteous declaration of the believer (Eph 2:18), and access to God (Eph 3:12) the consequence of the forgiveness of sins (Eph 3:12). This interpretation hinges upon faith as the means of apprehending Christ's righteousness. The interpretation gives human freedom a role in the salvation process. In Ephesians 3:12 it is not the appropriating of the work of Christ on the basis of our 'faith in him' and the resultant access to God. In view is our response to the work of Christ, the response of the freedom to make known the good news and the grounds of salvation as 'his faithfulness'.22 Van Unnik (1961:475) has

18.It is evident in the development of the idea of the church as a building

19.The household metaphor of Ephesians 5:21-32 is another example of a metaphor with missional dimension.

20.Goheen (2014:83) correctly distinguishes between missional dimension and intent in which he argues that 'every concept of the believer's and the believing community's life has a missional dimension. However, not all of the church's life has a missional intention'.

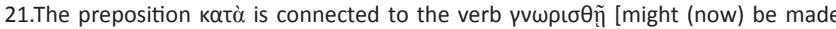
known] (Eph 3:10; cf. Hoehner 2002:463).

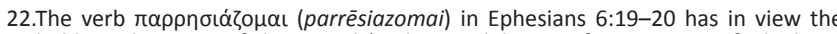
bold proclamation of the gospel (1 Th 2:2; Phil 1:20; cf. 2 Cor 3:12; cf. Thielman 2010:219). In this context the noun form is used. proposed an alternative interpretation: the reference in Ephesians 3:12 is to the public freedom of speech and refers to the believers' task to proclaim the gospel as opposed to the freedom to approach God. In the context it is a freedom of speech not primarily to God, but to one's neighbour. 'In the ancient Greek democracy, a citizen had the right to say anything publicly when the population was gathered for an assembly' (Schlier 1957:871). The freedom of believers to approach God is specifically in view in Ephesians 2:18. It is practically developed in Ephesians 3:10-12 as freedom of speech, to speak freely in the church and frankness of speech in the context of friendships and/or freedom to testify and witness to the gospel. In Ephesians 3:12 the freedom to proclaim the mystery is in view. The term $\pi \rho \circ \sigma \alpha \gamma \omega \gamma \eta$ has in view 'access' to the Father by one Spirit (Eph 2:18). In other words, it has in view the relation between believers in which both the vertical and horizontal dimensions are present and inseparably bound together. In Ephesians 3:12, however, the association of $\pi \rho \circ \sigma \alpha \gamma \omega \gamma \eta$ with such concepts and terms as $\pi \alpha \rho \rho \eta \sigma i \alpha$ [outspokenness] or [openness of speech in the public], [boldness] (New Revised Standard Version) or literal [courage] (cf. Heb 4:16, 10:31), and $\pi \varepsilon \pi$ oí $\theta \mu \_\varsigma$ [confidence], that is 'the extent of placing reliance or trust in or on the extent of placing reliance or trust in or on' (Louw \& Nida 1998:31.82), indicate that the freedom of speech to speak the gospel is in view. The missional context and focus of the letter as well as the wider context of Ephesians 3 favour such a reading of $\pi \rho \circ \sigma \alpha \gamma \omega \gamma \eta$ in the context. ${ }^{23}$ It is the reason that the interpretation of Van Unnik (1961:475) fits the context and the purpose of the letter. The reading of the letter through a missional purpose thus supports such an interpretation. The context of Ephesians 3:10, if interpreted through the lens of the missional purpose of the letter, is that of the spiritual beings intently looking into how the church fulfils its purpose as an instrument of God in the execution of the missio Dei (Eph 3:8-10; Van Aarde 2016). The missio Dei is concretely expressed in Ephesians 1:10 as the plan and purpose of God, and is expounded in Ephesians 1:314 in terms of the roles of the Father, Son and Holy Spirit in the plan and purpose of God. The concept of the missio Dei is developed and expressed in cosmic terms and dimensions as the mission of the church in Ephesians 1:15-23. It concretely developed in Ephesians 3 in terms of the participation of the church, Jew and Gentile in the missio Dei through the stewardship of the gospel. The priesthood of believers as the doctrine, which most aptly describes Ephesians 4:1-16, supports such an interpretation of Ephesians 3:12. The context in view is the freedom of speech to speak the gospel rather than access to God. The direct access all believers have to God (Eph 2:18) is developed further in Ephesians 3:12 in terms of their freedom to speak as part of the responsibility of every believer to minister to one another, to their unbelieving neighbours and to God (Eph 4:12-16). The idea of access to God (Eph 2:18) is connected to boldness and confidence to be publicly outspoken about faith in Christ (Eph 3:12) that is expressed and developed practically as 'speaking the truth in love' (Eph 4:15) to those inside and outside the church.

23.The generally accepted approach has been to read the term in light of the purpose of the letter, namely unity - a purpose with the context that both believing Jews and Gentiles are one entity and have access to God. 


\section{A biblical missional ecumenism}

The 'unity of the Spirit' (Eph 4:3) is more than a unity in terms of theological perspectives, worship style, church government and cultural patterns. It is primarily a unity in terms of the functioning together of the body of Christ that may be termed biblical missional ecumenism (cf. Van Wyk 2014:3, 4 among others). The confession of faith serves to build a biblical missional ecumenism. The goal of growing up into Christ is facilitated through cross-cultural and crossdenominational interaction, and pollination. In Ephesians 4:15 the ultimate goal towards which he and his readers are moving, is that 'together they may grow up into Christ, who is the head' (O'Brien 1999:310). The priesthood of believers has the function and role in missio Dei of binding, building and moving people together. This is the starting point for cross-denominational relations and seeing ways to work together in partnership and participate in God's mission. The goal towards which all believers, church and denominations are to move, is a greater faithfulness to the truth. In Ephesians 4:1-16 Love for the truth is the basis for a biblical missional ecumenism. It necessitates that we 'hold the truth' or 'speak the truth in love' (Eph 4:15). The consensus among interpreters is that the phrase, which literally means 'truthing in love', is to be understood as 'living out the truth in a spirit of love'. It is the truth spoken in love that has, as its basis, 'holding the truth in love'. It has transformative power power to transform both us and others. What we speak or hold is authenticated by a lifestyle that lovingly expresses the truth. The whole structure or body - the universal church - is fit together. This is a development of the idea of Ephesians $2: 21^{24}$ and builds itself up and out in love expressed in Ephesians 4:1-16:

It is also important to note that this passage makes it clear that ministry is not the obligation of a few but rather the responsibility of every believer. The unifying force is the oneness in purpose, that is, the use of gifts for body edification, not self-edification. (Hoehner 2002:579) ${ }^{25}$

\section{Conclusion}

In this article it is argued that the role of the laity in the missio Dei was one of the most significant developments followed by most church denominations. This article was developed along the same lines in the following traditions:

- The reformed tradition rediscovered the role of the laity in missions that the Baptist church tradition has now developed most extensively in terms of missions. Lutheranism may also be grouped with this division.

- The Catholic Church has recognised the Apostolicity of the laity in a decree called 'Apostolicam Actuositatem' at the Second Vatican Council in response to the crises of the church

- The charismatics gave recognition to the role of the laity through the spiritual gifts of each believer.

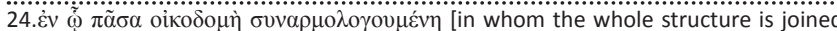
together] or [... fits together] (Eph 2:21)

25.'The distinction between clergy and laity is a human creation. This is due primarily to a confusion between gift and office' (Hoehner 2002:579).
It was further argued that the role of the laity and of the priesthood of believers has its biblical precedent and foundation in 1 Peter 2:5, 9 and Ephesians 4:1-16. The contribution of Ephesians is that it provides the church with a missional mandate for the ordinary believer to participate in the missio Dei - a mandate that has to be re-discovered in every age.

\section{Acknowledgements Competing interests}

The authors declare that they have no financial or personal relationships which may have inappropriately influenced them in writing this article.

\section{Authors' contributions}

T.A.v.A. contributed the missional perspective and insight on Ephesians. G.L. contributed the practical theological perspective and the dedication to Sarel van der Merwe.

\section{References}

Baldovin, J.F., 2011, 'Priesthood of all believers', in I.A. McFarland (ed.), The Cambridge dictionary of Christian theology, pp. 408-409, Cambridge University Press, Cambridge.

Balia, D. \& Kim, K., 2010, Edinburg 2010: Witnessing to Christ today, vol. 2, Regnum Books International, Oxford, UK (Regnum Edinburg Centenary Series).

Bosch, D., [1991] 2016, Transforming mission: Paradigm shifts in theology of mission, 20th anniversary edn., Orbis Books, Maryknoll, NY. (American Society of Missiology series, 16).

Brunsdon, A. \& Van der Merwe, S., 2013, 'From Mojadi to Mafikeng: Notes on the newfound Department of Theology', Studia Historiae Ecclesiasticae 39(1), 295-313.

Coleman, R.E., 2011, The heart of the gospel: The theology behind the master plan of evangelism, Baker Books, Grand Rapids, MI.

Driver, J., 1976, Community and commitment, Herald Printers, Scottsdale.

Goheen, M.W., 2014, Introducing Christian mission today: Scripture, history and ideas, IVP Academic, Downers Grove, IL.

Hastings, R., 2012, Missional God, missional church: Hope for re-evangelizing the west, IVP Academic, Downers Grove, IL.

Hoehner, H.W., 2002, Ephesians: An exegetical commentary, Grand Rapids: Baker Academic.

Holsten, W., 1939, 'Das Evangelium und Völker: beiträge zur Geschichte und Theorie der Mission, Buchhandlung der Gosnerischen Mission, Berlin-Friedenau.

Jørgensen, K., 2012, Equipping for service: Christian leadership in church and society Wipf \& Stock, Eugene, OR.

Louw, J.P. \& Nida, E.A., 1996, Greek-English lexicon of the New Testament: Based on semantic domains, United Bible Societies, New York.

Ma, W., 2007, 'When the poor are fired up: The role of pneumatology in PentecostalCharismatic mission', Transformation 24(1), 28-34. https://doi.org/10.1177/ 026537880702400105

O'Brien, P.T., 1999, The letter to the Ephesians, William B. Eerdmans Publishing, Grand Rapids, MI.

Padilla, R., 2004, 'Introduction: An ecclesiology for integral mission', in T. Yamamori \& R.C. Padilla (eds.), The local church, agent of transformation: An ecclesiology for integral mission, pp. 21-49, transl. B. Cordingly, Ediciones Kairós, Buenos Aires, Argentina.

Plüss, J.D., 2010, 'Pentecostal perspective on mission and unity', in K. Kim \& A. Anderson (eds.), Edinburg 2010: Mission today and tomorrow, vol. I, pp. 259-264 Regnum, Oxford. (Regnum Edinburg Series).

Rivers, R.S., 2005, From maintenance to mission: Evangelization and the revitalization of the parish, Paulist Press, New York.

Rogers, M., 2010, 'A dangerous idea? Martin Luther, E. Y. Mullins, and the priesthood of all believers', Westminster Theological Journal 72, 119-134.

Roldán, A.F., 2004, 'The priesthood of all believers and integral mission', in T. Yamamori \& R.C. Padilla (eds.), The local church, agent of transformation: An ecclesiology for integral mission, pp. 151-177, transl. B. Cordingly, Ediciones Kairós, Buenos Aires, Argentina.

Roxburg, A.J., 1996, The missionary congregation, leadership \& liminality, Trinity Press International, Valley Forge, PA

Second Vatican Council, 1965, Dogmatic constitution on the nature of the church, no. 31: A.A.S. 57, Article 3. 


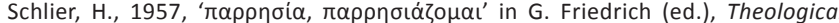
dictionary of the New Testament, vol. 5., pp. 871-886, Eerdmans, Grand Rapids.

Schultz, K.D., 2009, Mission from the cross: The Lutheran theology of mission, Concordia Publishing House, Saint Louis, OR.

Stronstad, R., 1999. The prophethood of all believers: A study in Luke's charismatic theology, Sheffield Academic Press, Sheffield.

Sunquist, S.W., 2013, Understanding Christian mission, Baker Academic, Grand Rapids, Ml.

Thielman, F., 2010, Ephesians: Baker exegetical commentary on the New Testament (ECNT), Baker Academic, Grand Rapids, MI.

Van Aarde, T.A., 2016, 'The use of oikovouia for missions in Ephesians', Verbum et Ecclesia 37(1), a1489. https://doi.org/10.4102/ve.v37i1.1489

Van der Walt, B.J., 2011, By the renewing of your mind: Shaping a biblical worldview and a Christian perspective on scholarship, Institute for Contemporary Christianity in Africa, Potchefstroom.
Van Rheenan, G. \& Parker, A., [1996] 2014, Missions: Biblical foundations and contemporary strategies, 2 nd edn., Zondervan, Grand Rapids, MI.

Van Unnik, W.C., 1961, 'The Christian freedom of speech in the New Testament', pape presented at the Manson Memorial Lectures, University of Manchester, 28th November.

Van Wyk, G., 2014, 'Missio-Dei as paradigma vir die verhouding tussen geloofsgemeenskappe', PhD-verhandeling, Noordwes Universiteit, Potchefstroom.

Virgo, T., 2011, The Spirit-filled church: Finding your place in God's purpose, Monarch Books, Oxford, UK.

Wengert, T.J., 2011, 'Priesthood, pastors, bishops: Public ministry for the reformation and today', in I.A. McFarland (ed.), The Cambridge dictionary of Christian theology, pp. 408-409, Cambridge University Press, Cambridge.

Woods, S.K. 2016 'The church: A people sent in mission', in K. Kim \& P. Grogan (eds.), The New evangelization: Faith, people, context and practice, pp. 65-78, T\&T Clark, London.

Young, J.T., 1993, 'Baptists and the priesthood of believers: Perspectives in religious studies', Journal for Baptist Theology \& Ministry 20(2), 131-146. 